\title{
ON THE PROBABLE ERROR OF SAMPLING IN SOIL SURVEYS.
}

\author{
By G. W. ROBINSON, B.A., \\ Adviser in Agricultural Chemistry, \\ AND W. E. LLOYD, B.Sc., \\ Research Scholar, University College of North Wales, Bangor.
}

THE following paper records experiments made to determine the magnitude of the error involved in the sampling of a soil for survey purposes. While it is not held that the results obtained are true for all localities, they serve to indicate the order of magnitude of the various errors.

The ordinary method of sampling a soil for survey purposes is, first to select a field uniform in itself and representative of the soil type which is being examined. Borings are then taken in various parts of the field. The borings from the top soil are united to form the soil sample. Similarly those from the subsoil are united to form the subsoil sample. The number of borings recommended in text-books is from five up to ten or twelve according to the size of the field sampled.

Now the probable error affecting the analysis of a single boring is a function of two probable errors, namely, (1) the laboratory error, that is the error of analytical determination (which itself includes an error of sampling from the laboratory sample), and (2) the field error, which is the error due to the normal variation in the composition of the soil from point to point in the field.

Now if the probable error of a determination on one boring be $P$, the probable laboratory error be $p_{1}$, and the probable field error be $p_{2}$,

$$
P=f\left(p_{1} p_{2}\right) \text {. }
$$

$P, p_{1}$ and $p_{2}$ will have different values according to the soil constituent which is determined. There will thus be a different set of $P, p_{1}$ and $p_{2}$ 
for nitrogen, phosphoric acid, coarse sand and so on. By a well-known formula

$$
P=\sqrt{p_{2}{ }^{2}+p_{1}} \text {, }
$$

provided that, as may be assumed to be the case, the errors are independent.

The object of this investigation is to obtain values of $p_{2}$, the probable field error, for various soil constituents.

There is practically no literature on the subject. The only account of previous work accessible to the writers is in a paper by J. W. Leather ${ }^{1}$. Leather took duplicate samples from several plots in different localities. Each sample consisted of a mixture of a dozen borings. He found that the differences between determinations on the duplicates of nitrogen, available phosphoric acid and potash respectively, varied from nothing up to more than 20 per cent. Unfortunately the data do not give any basis for determination of probable errors due to field variation ${ }^{2}$.

There are various papers which treat of the probable error of experimental plot yields, but since the composition of the soil is only one factor in determining crop yields, it cannot be expected that these probable errors are any measure of the probable error of sampling.

Two fields were therefore investigated, one on a drift and the other on a sedentary soil. The following notes describe the two fields.

Field A, at the College Farm, Aber, near Bangor. This field has been for many years in grass. The soil is glacial drift of local origin. It is not particularly uniform in texture and appearance and for ordinary survey purposes would be reckoned too variable.

Field B, at Cellar, Aberffraw, Anglesey. This field is now in arable cultivation. The soil is derived from the Pre-Cambrian schists. There is a certain admixture of wind blown sand since the field is not far from the sea. The soil is quite uniform in texture and appearance.

In Field A, 25 samples were taken. The diagram, Fig. 1, shows the order in which the borings were made.

Each sample was kept separately in a bag. On arrival at the laboratory all the samples were analysed according to the usual methods. The following analyses were performed: Mechanical analysis, determination of hygroscopic moisture and organic matter, and the

1 Trans. Chem. Soc. 1902, p. 883.

2 Since sending in this paper, the authors have seen a paper by Pfeiffer and Blanok, Landw. Versuchs. Stat. LXXVrr. Working on the nitrogen content of an experimental fieid, they obtained a field error of 2.5 per cent. This was, however, over a small area and the result is scarcely of service for survey purposes. 


\section{Probable Error of Sampling in Soil Surveys}

determination of the total $\mathrm{P}_{2} \mathrm{O}_{5}$. In the case of the $\mathrm{P}_{2} \mathrm{O}_{5}$ determinations it was felt that the error of analysis would be smaller if absolute determinations were made. Accordingly, the total $\mathrm{P}_{2} \mathrm{O}_{5}$ was determined by treatment with sodium peroxide.

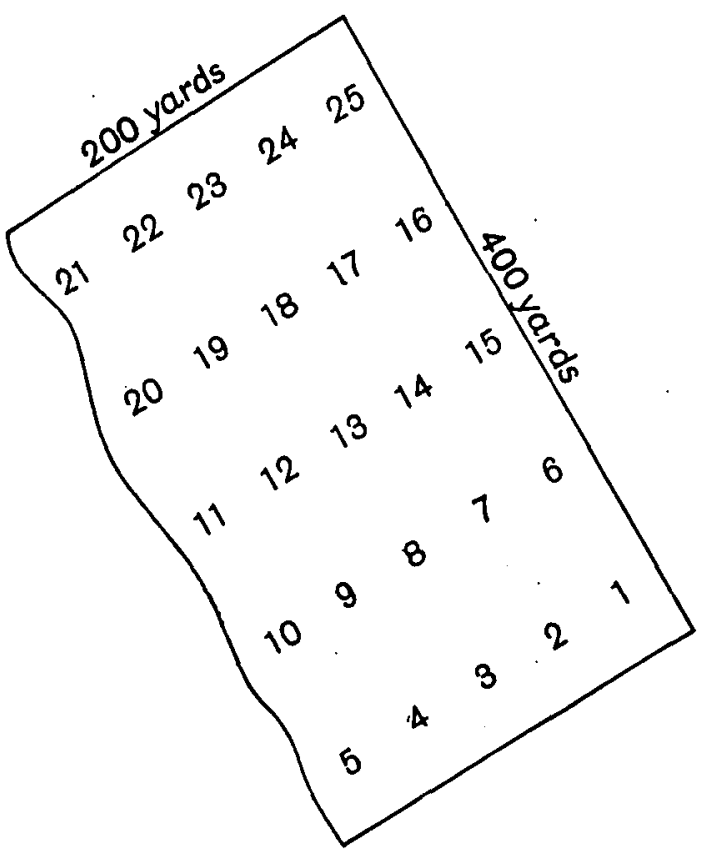

Fig. 1. Field A.

In order to get some idea of the reliability of the figures obtained i.e. to determine $p_{1}$, six mechanical analyses and $\mathrm{P}_{2} \mathrm{O}_{5}$ determinations were made of a well mixed composite sample of a number of borings. The results are shown in the following table.

Composite Sample.

\begin{tabular}{|c|c|c|c|c|c|c|c|}
\hline & $\begin{array}{l}\text { Fine } \\
\text { gravel }\end{array}$ & $\begin{array}{c}\text { Coarse } \\
\text { sand }\end{array}$ & $\begin{array}{l}\text { Fine } \\
\text { sand }\end{array}$ & Silt & $\begin{array}{l}\text { Fine } \\
\text { silt }\end{array}$ & Clay & $\mathrm{P}_{2} \mathrm{O}_{6}$ \\
\hline $\begin{array}{l}1 \\
2 \\
3 \\
4 \\
5 \\
6 \\
6\end{array}$ & $\begin{array}{l}7.93 \\
7.79 \\
7.90 \\
9.67 \\
8.03 \\
8.02\end{array}$ & $\begin{array}{l}16.31 \\
18.24 \\
17.56 \\
17.78 \\
17.75 \\
18.17\end{array}$ & $\begin{array}{l}15 \cdot 42 \\
15 \cdot 75 \\
15 \cdot 25 \\
15 \cdot 53 \\
15 \cdot 71 \\
14.99\end{array}$ & $\begin{array}{l}15 \cdot 30 \\
14 \cdot 84 \\
14 \cdot 73 \\
13 \cdot 65 \\
14 \cdot 45 \\
.14 \cdot 42\end{array}$ & $\begin{array}{l}24.21 \\
23 \cdot 81 \\
24 \cdot 65 \\
22.80 \\
24.44 \\
24.96\end{array}$ & $\begin{array}{l}4.80 \\
5.06 \\
4.20 \\
4.88 \\
5.09 \\
4.87\end{array}$ & $\begin{array}{r}\cdot 343 \\
\cdot 310 \\
\cdot 331 \\
\cdot 315 \\
.323 \\
.315\end{array}$ \\
\hline
\end{tabular}


The mean values and probable errors calculated from these figures are as follows:

\begin{tabular}{lccc} 
Constituent & Mean value & \multicolumn{2}{c}{ Probable error } \\
Fine gravel & $8 \cdot 22$ & $\pm \cdot 52= \pm 6 \cdot 3$ per cent. \\
Coarse sand & 17.63 & $\pm \cdot 54= \pm 3 \cdot 0 \quad "$ \\
Fine sand & $15 \cdot 43$ & $\pm \cdot 20= \pm 1 \cdot 3 \quad "$ \\
Silt & $14 \cdot 56$ & $\pm \cdot 38= \pm 2 \cdot 6 \quad "$ \\
Fine silt & $24 \cdot 14$ & $\pm \cdot 52= \pm 2 \cdot 1 \quad "$ \\
Clay & $4 \cdot 81$ & $\pm \cdot 11= \pm 2 \cdot 3 \quad "$ \\
$\mathrm{P}_{2} \mathrm{O}_{5}$ & .323 & $\pm \cdot 008= \pm 2.5 \quad "$
\end{tabular}

Similar determinations were not made for moisture and organic matter. The determinations are made with much less trouble than the mechanical analyses and $\mathrm{P}_{2} \mathrm{O}_{5}$ estimations, and therefore the moisture and organic matter were determined four times on each boring and averaged. The agreement was so close in all cases that $p_{1}$ for these determinations would be exceedingly small both absolutely and in comparison with the corresponding values of $P$ determined.

\begin{tabular}{|c|c|c|c|c|c|c|c|c|}
\hline $\begin{array}{c}\text { Fine } \\
\text { gravel }\end{array}$ & $\begin{array}{l}\text { Coarse } \\
\text { sand }\end{array}$ & $\begin{array}{l}\text { Fine } \\
\text { sand }\end{array}$ & Silt & $\begin{array}{c}\text { Fine } \\
\text { silt }\end{array}$ & Clay & $\begin{array}{l}\text { Mois- } \\
\text { ture }\end{array}$ & $\begin{array}{l}\text { Organic } \\
\text { matter }\end{array}$ & $\begin{array}{l}\text { Phos- } \\
\text { phorus } \\
\text { pent- } \\
\text { oxide } \\
\left(\mathrm{P}_{2} \mathrm{O}_{5}\right)\end{array}$ \\
\hline $\begin{array}{r}2 \cdot 43 \\
7 \cdot 33 \\
7 \cdot 84 \\
7.34 \\
7 \cdot 60 \\
11 \cdot 21 \\
6.32 \\
17 \cdot 25 \\
12 \cdot 14 \\
8 \cdot 37 \\
7 \cdot 42 \\
2 \cdot 63 \\
12 \cdot 49 \\
11 \cdot 20 \\
7.72 \\
2 \cdot 83 \\
8.20 \\
15 \cdot 35 \\
10.56 \\
7.38 \\
11 \cdot 49 \\
4.73 \\
4 \cdot 00 \\
2 \cdot 22 \\
3.10\end{array}$ & $\begin{array}{l}14 \cdot 56 \\
14 \cdot 80 \\
16 \cdot 02 \\
17 \cdot 27 \\
15 \cdot 95 \\
20 \cdot 32 \\
18 \cdot 71 \\
20 \cdot 36 \\
19 \cdot 57 \\
17.07 \\
14 \cdot 59 \\
11 \cdot 33 \\
22 \cdot 20 \\
16 \cdot 16 \\
16 \cdot 20 \\
11 \cdot 78 \\
17 \cdot 90 \\
19 \cdot 92 \\
22 \cdot 52 \\
21 \cdot 48 \\
20 \cdot 79 \\
22 \cdot 25 \\
19 \cdot 25 \\
11 \cdot 92 \\
16 \cdot 96\end{array}$ & $\begin{array}{l}18 \cdot 33 \\
19 \cdot 37 \\
19 \cdot 20 \\
21 \cdot 35 \\
16 \cdot 89 \\
18 \cdot 09 \\
16 \cdot 60 \\
14 \cdot 46 \\
14 \cdot 91 \\
19 \cdot 59 \\
20.87 \\
23 \cdot 37 \\
14 \cdot 35 \\
14 \cdot 72 \\
15 \cdot 67 \\
15 \cdot 31 \\
21 \cdot 38 \\
16 \cdot 09 \\
15 \cdot 52 \\
15 \cdot 13 \\
15 \cdot 74 \\
15 \cdot 96 \\
16 \cdot 76 \\
19 \cdot 83 \\
19 \cdot 66\end{array}$ & $\begin{array}{r}13 \cdot 78 \\
11 \cdot 79 \\
10.37 \\
8 \cdot 59 \\
10 \cdot 10 \\
8 \cdot 60 \\
14.95 \\
11 \cdot 31 \\
12.02 \\
11 \cdot 45 \\
13.56 \\
14 \cdot 12 \\
11 \cdot 51 \\
13.84 \\
13 \cdot 41 \\
16 \cdot 13 \\
12 \cdot 40 \\
10.40 \\
11 \cdot 39 \\
12 \cdot 93 \\
10 \cdot 57 \\
13.43 \\
15 \cdot 28 \\
.15 \cdot 96 \\
13 \cdot 21\end{array}$ & $\begin{array}{l}27 \cdot 63 \\
26 \cdot 47 \\
27 \cdot 99 \\
26 \cdot 73 \\
29 \cdot 38 \\
22 \cdot 65 \\
24 \cdot 30 \\
20 \cdot 10 \\
21 \cdot 93 \\
24 \cdot 90 \\
25 \cdot 12 \\
23 \cdot 03 \\
21 \cdot 45 \\
24.92 \\
27 \cdot 34 \\
33 \cdot 52 \\
24 \cdot 77 \\
21.44 \\
21 \cdot 25 \\
20 \cdot 00 \\
22 \cdot 65 \\
2 \cdot \cdot 12 \\
24 \cdot 25 \\
31 \cdot 53 \\
26 \cdot 50\end{array}$ & $\begin{array}{l}4 \cdot 18 \\
4 \cdot 11 \\
4 \cdot 06 \\
4 \cdot 07 \\
5 \cdot 28 \\
3 \cdot 46 \\
3 \cdot 66 \\
3 \cdot 26 \\
3 \cdot 00 \\
3 \cdot 64 \\
4 \cdot 47 \\
5 \cdot 54 \\
3 \cdot 42 \\
3 \cdot 54 \\
4 \cdot 35 \\
5 \cdot 40 \\
4 \cdot 30 \\
3.79 \\
4 \cdot 01 \\
3 \cdot 40 \\
4 \cdot 90 \\
3.75 \\
3.58 \\
4 \cdot 01 \\
6 \cdot 25\end{array}$ & $\begin{array}{l}\mathbf{3} \cdot 65 \\
\mathbf{4} \cdot 03 \\
3 \cdot 24 \\
3 \cdot 77 \\
3 \cdot 21 \\
2 \cdot 99 \\
3 \cdot 62 \\
2 \cdot 41 \\
2 \cdot 84 \\
3 \cdot 13 \\
2 \cdot 46 \\
2 \cdot 32 \\
2 \cdot 07 \\
2 \cdot 26 \\
1 \cdot 92 \\
2 \cdot 10 \\
1 \cdot 63 \\
2 \cdot 30 \\
2 \cdot 63 \\
2 \cdot 79 \\
2 \cdot 07 \\
2 \cdot 96 \\
2 \cdot 68 \\
2 \cdot 53 \\
2 \cdot 40\end{array}$ & $\begin{array}{r}12.83 \\
9 \cdot 94 \\
8 \cdot 55 \\
8 \cdot 59 \\
8 \cdot 89 \\
10.91 \\
11 \cdot 33 \\
9 \cdot 71 \\
12.25 \\
10.06 \\
9 \cdot 61 \\
9 \cdot 59 \\
9 \cdot 22 \\
11.26 \\
10 \cdot 30 \\
10 \cdot 30 \\
10 \cdot 75 \\
9 \cdot 10 \\
9 \cdot 65 \\
12.72 \\
9 \cdot 81 \\
13.14 \\
11 \cdot 69 \\
10 \cdot 16 \\
8 \cdot 89\end{array}$ & 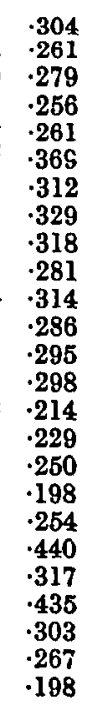 \\
\hline
\end{tabular}




\section{Probable Error of Sampling in Soil Surveys}

It will be seen from the values obtained above that with the exception of the fine gravel $p_{1}$ is about 2.5 per cent. as a maximum ${ }^{1}$. These figures are only obtained from six sets of determinations, but they are sufficiently accurate for the purpose of determining $p_{2}$, as will be seen later.

The table on p. 147 shows the results of the analyses of the 25 samples from Field A.

The mean values and probable errors calculated from these results are as follows:

\begin{tabular}{|c|c|c|c|}
\hline & Per cent. & \multicolumn{2}{|c|}{$\begin{array}{l}\text { Probable error per } \\
\text { cent. of result, } P\end{array}$} \\
\hline Fine gravel & \multicolumn{3}{|c|}{$7.92 \pm 2.78= \pm 35.0$ per cent. } \\
\hline Coarse sand & $17 \cdot 59 \pm 2.24$ & $= \pm 12.7$ & $"$ \\
\hline Fine sand & $17 \cdot 61 \pm 1 \cdot 64$ & $= \pm 9 \cdot 3$ & " \\
\hline Silt & $12.44 \pm 1.24$ & $= \pm 10 \cdot 0$ & , \\
\hline Fine silt & $26.50 \pm 2.71$ & $= \pm 10 \cdot 2$ & , \\
\hline Clay & $4 \cdot 10 \pm \cdot 52$ & $= \pm 12 \cdot 7$ & $"$ \\
\hline Moisture & $2.7 \pm \cdot 40$ & $= \pm 14.8$ & " \\
\hline Organic matter & $10.4 \pm .80$ & $= \pm 7 \cdot 7$ & $"$ \\
\hline Phosphorus pentoxide $\left(\mathrm{P}_{2} \mathrm{O}_{5}\right)$ & $\cdot 290 \pm \cdot 03$ & $= \pm 13 \cdot 4$ & , \\
\hline
\end{tabular}

In Field $B$ a set of 15 borings was taken as shown on the diagram Fig. 2.

The following results were obtained on analysis:

Aberffraw.

\begin{tabular}{|c|c|c|c|c|c|c|c|c|}
\hline $\begin{array}{c}\text { Fine } \\
\text { Gravel }\end{array}$ & $\begin{array}{l}\text { Coarse } \\
\text { sand }\end{array}$ & $\begin{array}{l}\text { Fine } \\
\text { sand }\end{array}$ & Silt & $\begin{array}{l}\text { Fine } \\
\text { silt }\end{array}$ & Clay & $\begin{array}{l}\text { Mois- } \\
\text { ture }\end{array}$ & $\begin{array}{l}\text { Organic } \\
\text { matter }\end{array}$ & $\mathrm{P}_{2} \mathrm{O}_{3}$ \\
\hline $\begin{array}{l}4 \cdot 45 \\
5 \cdot 73 \\
6 \cdot 13 \\
4 \cdot 15 \\
7 \cdot 57 \\
5 \cdot 58 \\
6 \cdot 05 \\
5 \cdot 24 \\
3 \cdot 37 \\
4 \cdot 50 \\
4 \cdot 95 \\
6 \cdot 64 \\
4 \cdot 77 \\
4 \cdot 02 \\
5 \cdot 40\end{array}$ & $\begin{array}{l}43 \cdot 39 \\
44 \cdot 12 \\
40 \cdot 79 \\
40 \cdot 41 \\
42 \cdot 30 \\
42 \cdot 05 \\
38 \cdot 97 \\
47 \cdot 50 \\
46 \cdot 74 \\
47 \cdot 36 \\
43 \cdot 56 \\
40 \cdot 85 \\
43 \cdot 43 \\
46 \cdot 25 \\
47 \cdot 46\end{array}$ & $\begin{array}{l}18 \cdot 04 \\
16.57 \\
16 \cdot 23 \\
16.80 \\
16.44 \\
16.59 \\
18.37 \\
14.39 \\
16.23 \\
16 \cdot 02 \\
17 \cdot 11 \\
17 \cdot 00 \\
16.98 \\
16.42 \\
16.56\end{array}$ & $\begin{array}{r}8 \cdot 52 \\
8 \cdot 42 \\
8 \cdot 81 \\
8 \cdot 55 \\
8 \cdot 78 \\
9 \cdot 20 \\
10 \cdot 06 \\
8 \cdot 70 \\
9 \cdot 53 \\
\mathbf{8} \cdot 58 \\
8 \cdot 98 \\
9 \cdot 65 \\
8 \cdot 12 \\
7 \cdot 53 \\
\mathbf{7} \cdot 35\end{array}$ & $\begin{array}{l}12 \cdot 91 \\
12.83 \\
13 \cdot 95 \\
14 \cdot 55 \\
14 \cdot 15 \\
14 \cdot 15 \\
14 \cdot 86 \\
13 \cdot 60 \\
12 \cdot 85 \\
12 \cdot 34 \\
12 \cdot 86 \\
14 \cdot 16 \\
13 \cdot 01 \\
12.82 \\
11.49\end{array}$ & $\begin{array}{l}3 \cdot 45 \\
3 \cdot 20 \\
3 \cdot 15 \\
3 \cdot 50 \\
3 \cdot 20 \\
3 \cdot 01 \\
3 \cdot 64 \\
3 \cdot 14 \\
3 \cdot 30 \\
3 \cdot 25 \\
3 \cdot 82 \\
3 \cdot 36 \\
3 \cdot 36 \\
3 \cdot 02 \\
3 \cdot 17\end{array}$ & $\begin{array}{l}2 \cdot 16 \\
2 \cdot 15 \\
2 \cdot 42 \\
1 \cdot 33 \\
1 \cdot 46 \\
2 \cdot 14 \\
2 \cdot 09 \\
2.02 \\
2 \cdot 00 \\
1.97 \\
1 \cdot 94 \\
2 \cdot 00 \\
2 \cdot 13 \\
1 \cdot 75 \\
2 \cdot 06\end{array}$ & $\begin{array}{l}\mathbf{5 \cdot 5 4} \\
\mathbf{5 \cdot 3 2} \\
\mathbf{6} \cdot 10 \\
\mathbf{6} \cdot 78 \\
\mathbf{5} \cdot 53 \\
\mathbf{5 \cdot 2 1} \\
\mathbf{5 \cdot 2 2} \\
\mathbf{5 \cdot 3 0} \\
\mathbf{5 \cdot 2 6} \\
\mathbf{4} \cdot 74 \\
\mathbf{5 \cdot 2 3} \\
\mathbf{4} \cdot 76 \\
\mathbf{5 \cdot 1 7} \\
\mathbf{5} \cdot 25 \\
\mathbf{4} \cdot 99\end{array}$ & $\begin{array}{l}\cdot 220 \\
\cdot 209 \\
\cdot 249 \\
\cdot 214 \\
\cdot 220 \\
\cdot 204 \\
\cdot 188 \\
\cdot 199 \\
\cdot 223 \\
\cdot 264 \\
\cdot 217 \\
\cdot 179 \\
\cdot 269 \\
\cdot 229 \\
\cdot 213\end{array}$ \\
\hline
\end{tabular}

1 In mechanical analyses this error will be much greater if the temperature of eedimentation is not constant, owing to viscosity changes. 


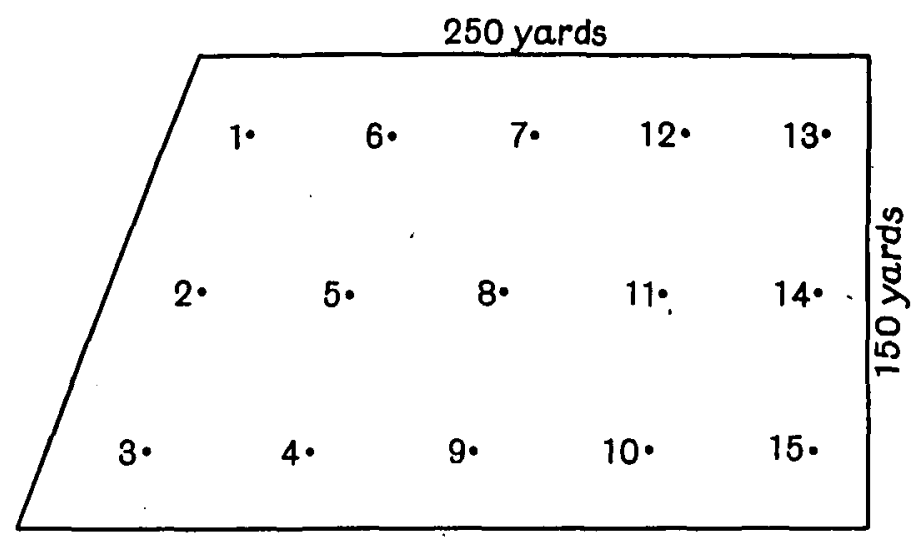

Fig. 2. Field B.

The mean values and probable errors calculated from these results are as follows:

\begin{tabular}{|c|c|c|c|}
\hline & Per cent. & \multicolumn{2}{|c|}{$\begin{array}{c}\text { Probable error per cent. } \\
\text { of resilt, } P\end{array}$} \\
\hline Fine gravel & $5 \cdot 23 \pm \cdot 73$ & \pm 13.9 & er cent. \\
\hline Coarse sand & $43 \cdot 68 \pm 1 \cdot 76$ & \pm 4.0 & " \\
\hline Fine sand & $16 \cdot 65 \pm \cdot 45$ & $\pm 2 \cdot 7$ & $\Rightarrow$ \\
\hline Silt & $8.73 \pm .48$ & $\pm 5 \cdot 5$ & $"$ \\
\hline Fine silt & $13 \cdot 37 \pm \cdot 60$ & $\pm 4 \cdot 5$ & $"$. \\
\hline Clay & $3 \cdot 30 \pm \cdot 13$ & \pm 3.9 & $"$ \\
\hline Moisture & $1.97 \pm .18$ & $\pm 9 \cdot 2$ & " \\
\hline Organic matter & $5.36 \pm .235$ & $\pm 4 \cdot 4$ & $"$ \\
\hline Phosphorus pentoxide $\left(\mathrm{P}_{2} \mathrm{O}_{5}\right)$ & $\cdot 220 \pm \cdot 017$ & $\pm 7 \cdot 7$ & :, \\
\hline
\end{tabular}

The results obtained may now be stated:

Field A. Drift Soil.

\begin{tabular}{|c|c|c|c|}
\hline Determination made & $\begin{array}{c}P \\
\text { (per cent.) }\end{array}$ & $\begin{array}{c}p_{1} \\
\text { (per cent.) }\end{array}$ & $\begin{array}{c}p_{2}\left(=\sqrt{\left.P^{2}-p_{1}^{2}\right)}\right. \\
\text { (per cent.) }\end{array}$ \\
\hline Fine gravel & $35 \cdot 0$ & $6 \cdot 3$ & $\mathbf{3 4 . 5}$ \\
\hline Coarse sand & $12 \cdot 7$ & $3 \cdot 0$ & $12 \cdot 3$ \\
\hline Fine sand & $9 \cdot 3$ & $1 \cdot 3$ & $8 \cdot 2$ \\
\hline Silt & $10 \cdot 0$ & $2 \cdot 6$ & $9 \cdot 7$ \\
\hline Fine silt & $10 \cdot 2$ & $2 \cdot 1$ & $10 \cdot 0$ \\
\hline Clay & $12 \cdot 7$ & $2 \cdot 3$ & $12 \cdot 4$ \\
\hline Moisture & \multirow{2}{*}{\multicolumn{2}{|c|}{\begin{tabular}{r|c}
14.8 & v. small since mean \\
7.7 & of 4 was taken
\end{tabular}}} & $14 \cdot 8$ \\
\hline Organic matter & & & $7 \cdot 7$ \\
\hline $\mathrm{P}_{2} \mathrm{O}_{8}$ & $13 \cdot 4$ & $2 \cdot 5$ & $13 \cdot 2$ \\
\hline
\end{tabular}


Field B. Sedentary Soil.

\begin{tabular}{|c|c|c|c|}
\hline Determination made & $\begin{array}{c}P \\
\text { (per cent.) }\end{array}$ & $\begin{array}{c}p_{1} \\
\text { (per cent.) }\end{array}$ & $\begin{array}{c}p_{2}\left(=\sqrt{P^{2}-p_{1}^{2}}\right. \\
\text { (per cent.) }\end{array}$ \\
\hline Fine gravel & $13 \cdot 9$ & $6 \cdot 3$ & $12 \cdot 4$ \\
\hline Coarse sand & $4 \cdot 0$ & $3 \cdot 0$ & $2 \cdot 6$ \\
\hline Fine sand & $2 \cdot 7$ & $1 \cdot 3$ & $2 \cdot 4$ \\
\hline Silt & $5 \cdot 5$ & $2 \cdot 6$ & 4.8 \\
\hline Fine silt & 4.5 & $2 \cdot 1$ & $4 \cdot 0$ \\
\hline Clay & $3 \cdot 9$ & $2 \cdot 3$ & $3 \cdot 1$ \\
\hline Moisture & $\left.\begin{array}{l}9 \cdot 2 \\
4.4\end{array}\right\} \nabla$. & $\begin{array}{l}4 \text { all since mean } \\
4 \text { was taken }\end{array}$ & $\begin{array}{l}9 \cdot 2 \\
4 \cdot 4\end{array}$ \\
\hline $\begin{array}{l}\text { Organic matter } \\
\mathrm{P}_{2} \mathrm{O}_{5}\end{array}$ & $\begin{array}{l}4 \cdot 4 \\
7 \cdot 7\end{array}$ & $\begin{array}{l}4 \text { was taken } \\
2.5\end{array}$ & $\begin{array}{l}4 \cdot 4 \\
7 \cdot 3\end{array}$ \\
\hline
\end{tabular}

Practically the same values for $p_{2}$ might have been obtained if analyses had been repeated several times for each boring and averaged. The values of $p_{1}$ would then have been greatly reduced and consequently, as in the case of the moisture and organic matter, $p_{2}$ could be taken as approximately equal to $P$.

In view of the great time taken in making soil analyses it was felt that the increase in the accuracy of the values of $p_{2}$ which would thus be obtained would scarcely be great enough to justify spending four or five times as long over the laboratory work. Also, no time was spent in doing chemical analyses other than the determination of $\mathrm{P}_{2} \mathrm{O}_{5}$.

It is seen from the above tables that in the case of Field A, which is too variable for ordinary survey purposes, $p_{2}$ is as great as 34.5 per cent. for fine gravel. Now this constituent is comparatively unimportant in characterising a soil unless it predominates over other fractions. An accurate knowledge of the hygroscopic moisture is also, for survey purposes, of no great importance. Of the other determinations the probable field errors of the fractions in the mechanical analysis are about 10 per cent., while that of the $\mathrm{P}_{2} \mathrm{O}_{5}$ is 13.4 per cent.

If therefore we count on a probable error of 13.4 per cent. for this soil this can be taken as a maximum value. Similarly 7.3 per cent. can be taken as the maximum value of the field error for Field $B$ which is a sedentary soil. Field $A$ is as stated above of too variable a character for ordinary survey purposes. If therefore operations are conducted on the basis of a maximum field error of 10 per cent. it will probably serve for survey work.

The value of the total probable error of the final result can now be reduced to any desired value by increasing the number of borings and the number of determinations. 
Thus if $n$ borings are made and one determination made on each boring the probable error of the average is

$$
\pm \frac{\sqrt{p_{1}^{2}+p_{2}^{2}}}{\sqrt{n}} \text { or } \frac{P}{\sqrt{n}} \text {. }
$$

For example, in the case of $\mathrm{P}_{2} \mathrm{O}_{5}$ in Field $\mathrm{A}, 9$ borings separately analysed and averaged would give a probable error of

$$
\pm \frac{13 \cdot 4}{\sqrt{9}}= \pm 4 \cdot 46 \text { per cent. }
$$

If $n$ borings are made and a composite sample obtained by mixing, the field error will be reduced to $\frac{p_{2}}{\sqrt{ } n}$, but the laboratory error will still be present, so that if 9 borings from Field B were mixed, the error of one analysis would be

$$
\pm \sqrt{2 \cdot 5^{2}+\left(\frac{13 \cdot 2}{v^{9}}\right)^{2}}, \text { or } \pm 5 \cdot 05 \text { per cent. }
$$

Where the field error is large in comparison with the laboratory error not much additional accuracy is obtained by analysing the borings separately. Also, however many borings are taken and mixed, it is not possible to reduce the final error to less than the laboratory error; and it is also somewhat difficult to ensure the satisfactory mixing of a very large number of borings.

Performing more than one analysis on a composite sample will serve to reduce the laboratory error, and consequently the final error of result.

If the field error for chemical analyses be taken as \pm 10 per cent. and that for the mechanical analyses as \pm 5 per cent., we shall probably not err on the side of minimising errors, since no field is sampled for survey purposes unless it appears fairly uniform. As is mentioned above, Field A would not be considered uniform enough for survey purposes.

The following table shows the probable error of final result for different numbers of borings and for single and duplicate analyses of the mixed sample. The probable errors are calculated on the assumption that the final probable error is equal to the square root of the sum of the squares of the separate probable errors. Thus the probable error of an average of two determinations on a composite sample of 5 borings is in the case of mechanical analyses equal to

$$
\pm \sqrt{\left(\frac{2 \cdot 5}{\sqrt{ } 2}\right)^{2}+\left(\frac{5}{\sqrt{5}}\right)^{2}}= \pm 2.8 \text { per cent., }
$$

Joprn. of Agrio. Soi. va 


\section{Probable Error of Sampling in Soil Surveys}

and in the case of a chemical analysis,

$$
\pm \sqrt{\left(\frac{2 \cdot 5}{\sqrt{ } 2}\right)^{2}+\left(\frac{10}{\sqrt{ } 5}\right)^{2}}= \pm 4 \cdot 8 \text { per cent. }
$$

\begin{tabular}{|c|c|c|c|c|}
\hline \multirow{3}{*}{$\begin{array}{l}\text { Number of } \\
\text { borings } \\
\text { taken and } \\
\text { mixed to form } \\
\text { composite } \\
\text { sample }\end{array}$} & \multicolumn{4}{|c|}{ Final probable error, per cent. } \\
\hline & \multicolumn{2}{|c|}{$\begin{array}{l}\text { Mechanical analysis } \\
\left(p_{\mathbf{2}}= \pm 5 \text { per cent. }\right)\end{array}$} & \multicolumn{2}{|c|}{$\begin{array}{c}\text { Chemical analysis } \\
\left(p_{2}= \pm 10 \text { per cent. }\right)\end{array}$} \\
\hline & $\begin{array}{l}\text { Single } \\
\text { analysis }\end{array}$ & $\begin{array}{l}\text { Average of } \\
\text { two analyses }\end{array}$ & $\begin{array}{l}\text { Single } \\
\text { analysis }\end{array}$ & $\begin{array}{l}\text { Average of } \\
\text { two analyses }\end{array}$ \\
\hline $\begin{array}{r}1 \\
2 \\
3 \\
4 \\
5 \\
6 \\
7 \\
8 \\
9 \\
9 \\
10\end{array}$ & $\begin{array}{l} \pm 5 \cdot 6 \\
\pm 4 \cdot 3 \\
\pm 3 \cdot 8 \\
\pm 3 \cdot 5 \\
\pm 3 \cdot 3 \\
\pm \mathbf{3 \cdot 2} \\
\pm \mathbf{3} \cdot 1 \\
\pm \mathbf{3} \cdot 05 \\
\pm \mathbf{3} \cdot 0 \\
\pm 2 \cdot 95\end{array}$ & $\begin{array}{l} \pm 5 \cdot 3 \\
\pm 3 \cdot 95 \\
\pm 3 \cdot 5 \\
\pm 3 \cdot 05 \\
\pm 2 \cdot 8 \\
\pm 2 \cdot 7 \\
\pm 2 \cdot 6 \\
\pm 2 \cdot 5 \\
\pm 2 \cdot 4 \\
\pm 2 \cdot 35\end{array}$ & $\begin{array}{l} \pm 10.3 \\
\pm 7.5 \\
\pm \quad 6.3 \\
\pm \pm .6 \\
\pm 5.6 \\
\pm 5.1 \\
\pm 4.8 \\
\pm 4.5 \\
\pm \pm .3 \\
\pm 4.15 \\
\pm 4.0\end{array}$ & $\begin{array}{l} \pm 10.1 \% \\
\pm \quad 7.3 \\
\pm \quad 6.0 \\
\pm 5.3 \\
\pm 4.8 \\
\pm \pm .4 \\
\pm \pm .2 \\
\pm \quad 3.95 \\
\pm \quad 3.75 \\
\pm 3.6 .\end{array}$ \\
\hline
\end{tabular}

The table shows that even with 10 borings there is not much diminution in the probable error by taking an average of two analyses. Since however some check is advisable it is better to make two analyses.

When two mechanical analyses are performed it is seen that not much additional accuracy is obtained by increasing the number of borings beyond six, either in the mechanical or chemical analyses. Taking six as the number of borings the probable error is \pm 2.7 per cent. This means that it is an even chance that a result obtained is within $2 \cdot 7$ per cent. of the true result. The chances of a result having lower degrees of accuracy are shown in the following table, calculated from Wood and Stratton's paper on the Interpretation of Experimental results ${ }^{1}$.

$\begin{gathered}\text { Percentage deviation } \\ \text { from true value }\end{gathered}$
$\begin{array}{rl}\begin{array}{c}\text { Chances of result being within } \\ \text { limits of such deviation }\end{array} \\ 3 \cdot 4 \text { per cent. } & \text { Evens } \\ 3 \cdot 9 & 3 \text { to } 2 \\ 4 \cdot 6 & 2 \text { to } 1 \\ 5 \cdot 1 & 3 \text { to } 1 \\ 5 \cdot 4 & 4 \text { to } 1 \\ & \text { 3 This Journal, Vol. m. p. } 429 .\end{array}$


Similarly in the case of a chemical analysis, we have for six borings:

$\begin{gathered}\text { Percentage deviation } \\ \text { from true value }\end{gathered}$
4.4 per cent.
5.5 ".
$6 \cdot 3 \quad$ "
$7 \cdot 5 \quad$ "
$8 \cdot 3 \quad$ ".
$8.8 . . . "$

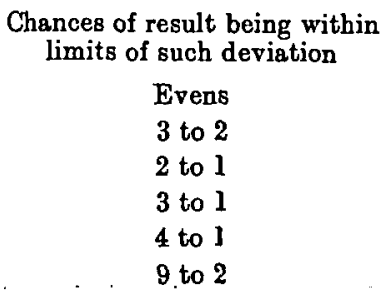

From these results it is seen that an accuracy of 5 per cent. in mechanical analysis is ensured a probability of 4 to 1 by doing a duplicate analysis on six borings. For survey purposes this is probably sufficient, since it is not conceivable that variation in the amount of any fraction corresponding to 5 per cent. (relative to the amount of the fraction) could have any effect on the properties of a soil.

In the case of chemical analysis it does not seem that the same accuracy can be expected. For survey purposes however the accuracy is probably sufficient. In the case of a critical study of one soil however it would be necessary to reduce the errors much more by repeating analyses and increasing the number of borings.

(Received March 3rd, 1915.) 